\title{
Evolution of the eastern part of the Kuusamo Ice Lobe, based on geomorphological interpretation of high-resolution LiDAR data
}

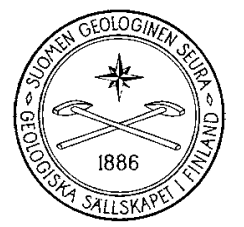

VERTAISARVIOITU KOLLEGIALT GRANSKA PEER-REVIEWED

\author{
PertTi Sarala* and JukKa Räisänen \\ Geological Survey of Finland, P.O. Box 77, FI-96101 Rovaniemi, Finland
}

\begin{abstract}
In this article, we present new glacial geomorphological data from the eastern part of the Kuusamo Ice Lobe (KIL) in eastern Finland. The focus is on glacial lineations (about 9000 individual features) and interpretation of ice lobe evolution based on streamlined erosional and depositional formations, hummocky and ribbed moraines and glaciofluvial formations. Glacial geomorphological mapping was performed based on interpretation and classification of LiDAR data according to the Geological Survey of Finland's new Glacier Dynamic database. The results revealed that modern surficial deposits were formed during three different ice flow phases. The oldest remains are seen as occasional NW-SE megalineations and unclassified glacially lineated terrains and erosional valleys representing the Middle Weichselian glaciation. The younger morphologies were formed from the two overlapping drumlin fields of the Tuoppajärvi and Kuusamo ice flow phases, with origins in the Late Weichselian deglaciation. Analysis of different erosional and depositional formation patterns was used to separate ice flow phases and estimate the evolution, subglacial conditions and mass balance of KIL during the last deglaciation. The morphological interpretation revealed that the Tuoppajärvi ice flow stage was large and homogeneous, while the later Kuusamo ice flow stage was more concentrated, narrower and heterogeneous, following a fan-type pattern that is also emphasised by the meltwater channel systems, including both erosional and depositional features. Furthermore, on both margins (northern and southern), part of the ice masses formed stagnant areas. The length of the lineations also indicates both glacier flow velocity and transport distances, which in the case of megalineations and drumlins are longer than in the fluted terrain. Ribbed moraines in the western (core part) of KIL indicate a very different depositional environment relating to strong quarrying and short transport distances under cold-based subglacial conditions, near the core area and the late ice divide zone of the Scandinavian Ice Sheet.
\end{abstract}

Keywords: Glaciodynamics, ice lobe, lineation, drumlin, fluting, ribbed moraine, Kuusamo, Finland

*Corresponding author (e-mail: pertti.sarala@gtk.fi)

Editorial handling: Antti Ojala (antti.ojala@gtk.fi) 


\section{Introduction}

Active ice lobes can be used as an indicator of glaciodynamics and balancing in the ice mass configuration of continental ice sheets. Together with streamlined lineations, meltwater channel patterns and marginal formations, an ice lobe network can be used in reconstructing glacier evolution during the retreat phase of an ice sheet (e.g. Clark \& Stokes, 2003; Kleman et al., 2006). In Finland, in the central part of the Scandinavian Ice Sheet (SIS), ice lobe identification until now has been based on morphological reconstruction of moraine and glaciofluvial formations using satellite and aerial image interpretation, as well as field mapping (e.g. Aario \& Forsström, 1979; Kurimo, 1982; Punkari, 1997; Johansson \& Kujansuu, 2005a; Sarala, 2005a).

Recent glaciomorphological studies in glaciated terrain have shown that the aerial light detection and ranging (LiDAR)-derived digital elevation model (DEM) is a breakthrough method in recognising morphological features and even the smallest surficial details of landforms (Smith \& Patterson, 2014; Möller \& Dowling, 2015; Ojala et al., 2015; Sarala et al., 2015). In addition to moraine landforms, it is also possible to distinguish several glaciofluvial and till-covered delta or sandur deposits based on LiDAR (Sarala et al., 2015).

The use of LiDAR in geomorphological mapping of glaciogenic morphologies in certain ice lobe areas in Finland started in 2015, in an inhouse project at the Geological Survey of Finland (GTK) (Putkinen et al., 2016). As part of the project, mapping and interpretation were carried out in the area of the Kuusamo Ice Lobe (KIL) in 2016. In this article, we present new morphological data obtained during that work, focusing on the glacial lineations, glaciofluvial systems and hummocky and ribbed moraines, and propose an interpretation of ice lobe evolution based on these data. The classification of the glaciomorphology follows the new geomorphological database described by Putkinen et al. (2017, in this volume).

\section{Study area}

The study area is located in southern Finnish Lapland and Koillismaa in northern Finland (Fig. 1). The onset area of KIL is located in western Finnish Lapland and reaches from there to the Kuusamo area in the east, with a generalised ice flow direction from west to east. The focus in this study focus was on the eastern part of KIL, covering about $16000 \mathrm{~km}^{2}$. Figure 1 shows the location of the study area, with the main morphology areas and borders. KIL is known for the presence of the large Kuusamo drumlin field described earlier by Aario (1977) and Aario \& Forsström (1979). According to GTK's Quaternary deposits database, the drumlin field comprises about 2400 single drumlin ridges (Johansson \& Kujansuu, 2005b). Furthermore, there are numerous smaller streamlined features (e.g. flutings) in conjunction with the drumlins (Aario, 1977; Aario, 1990).

According to Aario \& Forsström (1979), the formation of the drumlin field occurred in two flow phases during the last deglaciation. The first phase represents an earlier Late Weichselian flow stage called the Tuoppajärvi phase, of which the west-east orientated Tuoppajärvi drumlin field is a remnant. After the margin of that ice stream reached the Pääjärvi area in Russian Karelia, it was reoriented to form KIL, which created a drumlin field over the Tuoppajärvi drumlin field (Aario, 1990). The most favourable conditions for the Kuusamo drumlin field occurred after the Younger Dryas stage, when the glacier melted rapidly and active ice lobes were a surging type (Sarala, 2005a).

Johansson \& Kujansuu (2005b) have estimated that the margin of KIL was in the eastern Kuusamo area about 10500 years ago. Within the next 200300 years, the ice melted away and the margin reached western Finnish Lapland about 10300 10200 years ago. A couple of small ice lakes, Kitka and Kuusamo (the highest shoreline about $252 \mathrm{~m}$ above present sea level (a.s.l.)) formed on the edge of the eastern margin before the main proglacial ice lake phase, Lake Ancylus, the highest shoreline 


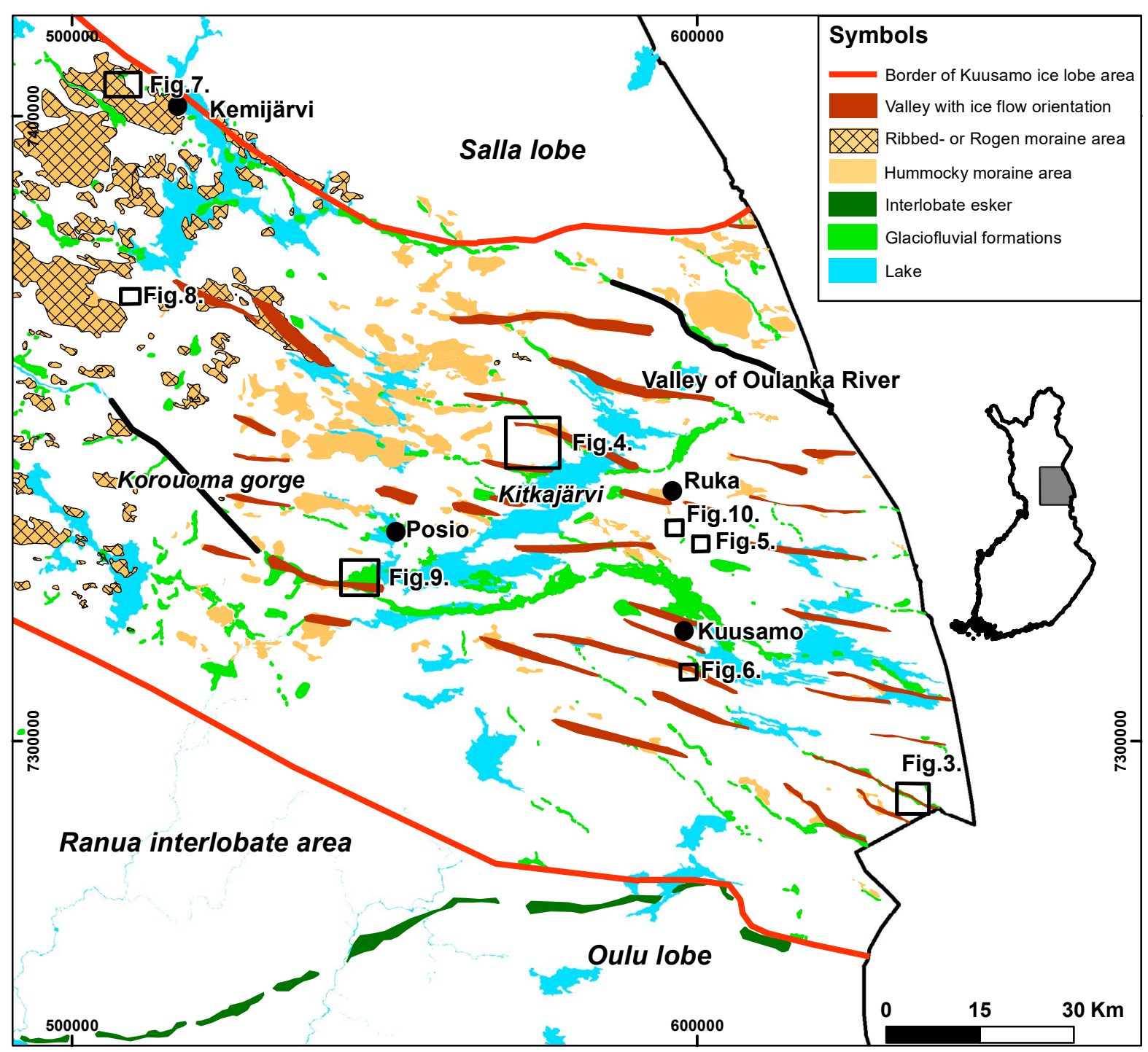

Figure 1. Location of the Kuusamo Ice Lobe (KIL) and its glaciofluvial formations, hummocky and ribbed moraines areas and streamlined valleys. Map produced by J. Räisänen. Coordinate system: EUREF-FIN.

of which was at $195-210 \mathrm{~m}$ a.s.l. in the study area (Heikkinen \& Kurimo, 1977; Johansson, 2005).

The bedrock in the KIL area is composed of three main lithological areas (Korsman \& Koistinen, 1998). Rocks in the southern part are Archaean gneisses and migmatites. The eastern and northern parts are included in the Palaeoproterozoic Central Lapland granitoid complex with granites. The Palaeoproterozoic Peräpohja Schist Belt with sedimentary and volcanic rocks, schists and migmatites dominate in the western parts. Dolomites are common in eastern areas, particularly in the valley of the Oulankajoki River (Silvennoinen, 1991). The highest hills in the area are formed from quartzites that are a remnant of 1800 million-yearold mountains from the latest orogeny phase in the area (Räisänen et al., 2012). The highest point in the area is Rukatunturi Fell (491 m a.s.l.), about $25 \mathrm{~km}$ 
north from Kuusamo town. Some major shear zones and gorge valleys exist in the area and are evident as the main river valleys, such as the Oulankajoki River in the east and the Korouoma Gorge valley in the centre.

\section{Methods}

The present mapping of different morphological features was mainly based on interpretation of the LiDAR data, which cover almost the whole KIL area apart from some parts in the south. The LiDAR data used were based on the Finnish National Land Survey's flights in 2011-2015. The density of these LiDAR data is a minimum of 0.5 signal points per square metre, which leads to a digital elevation model with $2 \mathrm{~m} \times 2 \mathrm{~m}$ horizontal and $0.3 \mathrm{~m}$ vertical resolution. For the visualisation of the LiDAR DEM, both hill shading using NW light with angle $30^{\circ}$ and multidirectional shading were used. The mapping process was carried out using ArcMap 10.3/10.4 software.

The geomorphological interpretation process was supported by reference to the old mapping data revision, including old Quaternary geological maps, and GTK's surficial morphology database, RukaOulanka outdoor map (Räisänen et al., 2012) and earlier literature (e.g. Kurimo, 1974; Aario, 1977; Aario \& Forsström, 1979; Sutinen, 1992; Johansson \& Kujansuu, 2005a; Sarala, 2005a).

This article presents the glacial morphological interpretation for the eastern part of KIL, based mainly on the moraine morphologies and lineations indicative of glacial ice flow directions and activity. Figure 2 shows the interpreted ice flow directions over the LiDAR-based digital elevation model. About 9000 different types of lineations were mapped and classified into one of five categories based on the GTK's Glacier Dynamic database (see Putkinen et al., 2017 in this volume). These were: drumlins, megascale glacial lineations (MSGLs), rock drumlins, pre-crags and flutings. The term 'glacially lineated terrain' was used for lineation areas that could not be classified into one of these five categories. Direction and length of each feature were measured and the lineations were marked as line elements (see the description in Figure 3). Examples of different types are presented in Figures 4-10.

\section{Results}

Different types of glacial lineation features dominate the eastern part of KIL. The densest feature concentration is in the eastern part, on the southern and eastern sides of Kuusamo town (Fig. 2). Numerous lineation features are also found in the east, from the lakes Ruka and Kitkajärvi. The number of lineations decreases strongly towards the centre of the mapped area and from there to the west, where the glacial features change into hummocky and ribbed moraine morphologies. Lineation mapping revealed that there is no major bedrock lithological or structural control for the existence or orientation of lineation features. However, a remarkable finding was that lineations are lacking in the areas with dolomite rocks.

\subsection{Streamlined lineation features}

The longest lineation features are around $7 \mathrm{~km}$ in length and were classified as megaflutings. They are particularly common on the distal side of the highest hills or high land areas and indicate the glacial flow direction and dynamics of the main ice lobe body. Other components in these streamlined features are small, narrow flutings or a group of small flutings which form a fluted surface. The length of the single ridges may be only some tens of metres. They are present in very variable environments, although usually in close conjunction to other streamline features. Furthermore, flutings are commonly found superimposing other morphologies such as hilltops, large drumlins and ribbed moraines. In addition, it is possible to see some remnants of ancient ice flow stages under the younger morphology as larger features such as erosional valleys or MSGLs 


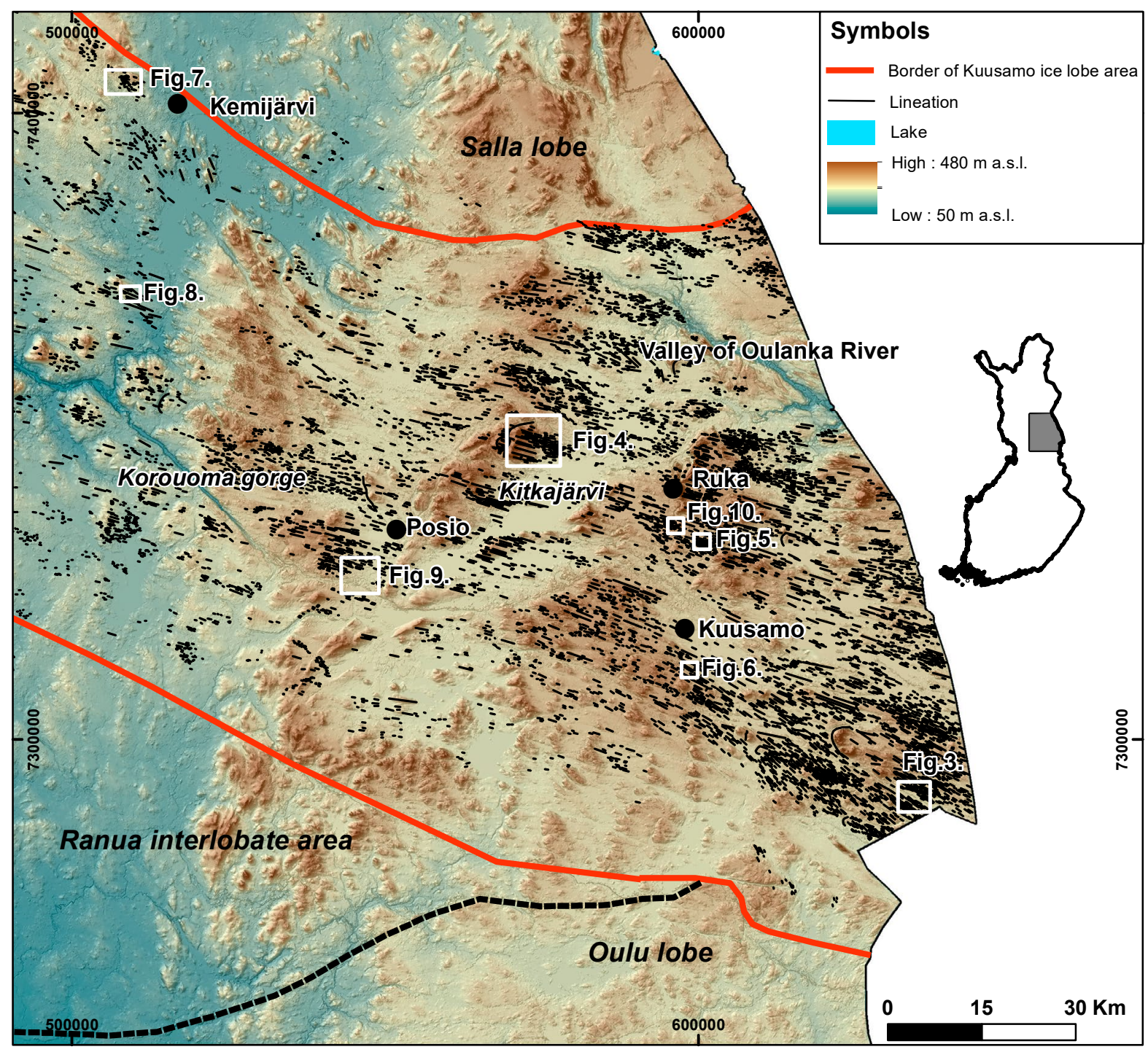

Figure 2. The mapped area of the Kuusamo Ice Lobe (KIL), which comprises more than 9000 single lineation features. Examples of these are presented in Figures 3-10 and described in detail in the text. Map produced by J. Räisänen. Coordinate system: EUREF-FIN.

with a northwest-southeast orientation. Of these, some long narrow lakes near Kuusamo centre and the Ruka area and MSGLs in the northeastern hummocky moraine area are examples. Lineations and erosional features with the same orientation become more common on moving towards the core area of KIL (i.e. Kemijärvi-Rovaniemi and Tervola areas) in the west (e.g. Sarala, 2005a; Sarala \& Rossi, 2006).
Drumlins are the most common streamlined features in eastern KIL. They include both rock-core forms like crags and tails, rock-core drumlins and pre-crags and sediment-based drumlins composed mostly of till, but also stratified sediments (cf. Aario, 1990). They occur as two drumlin fields with the indication of different flow directions. This is best seen as overlapping drumlin ridges in the south-eastern part of KIL (Fig. 3). The underlying 


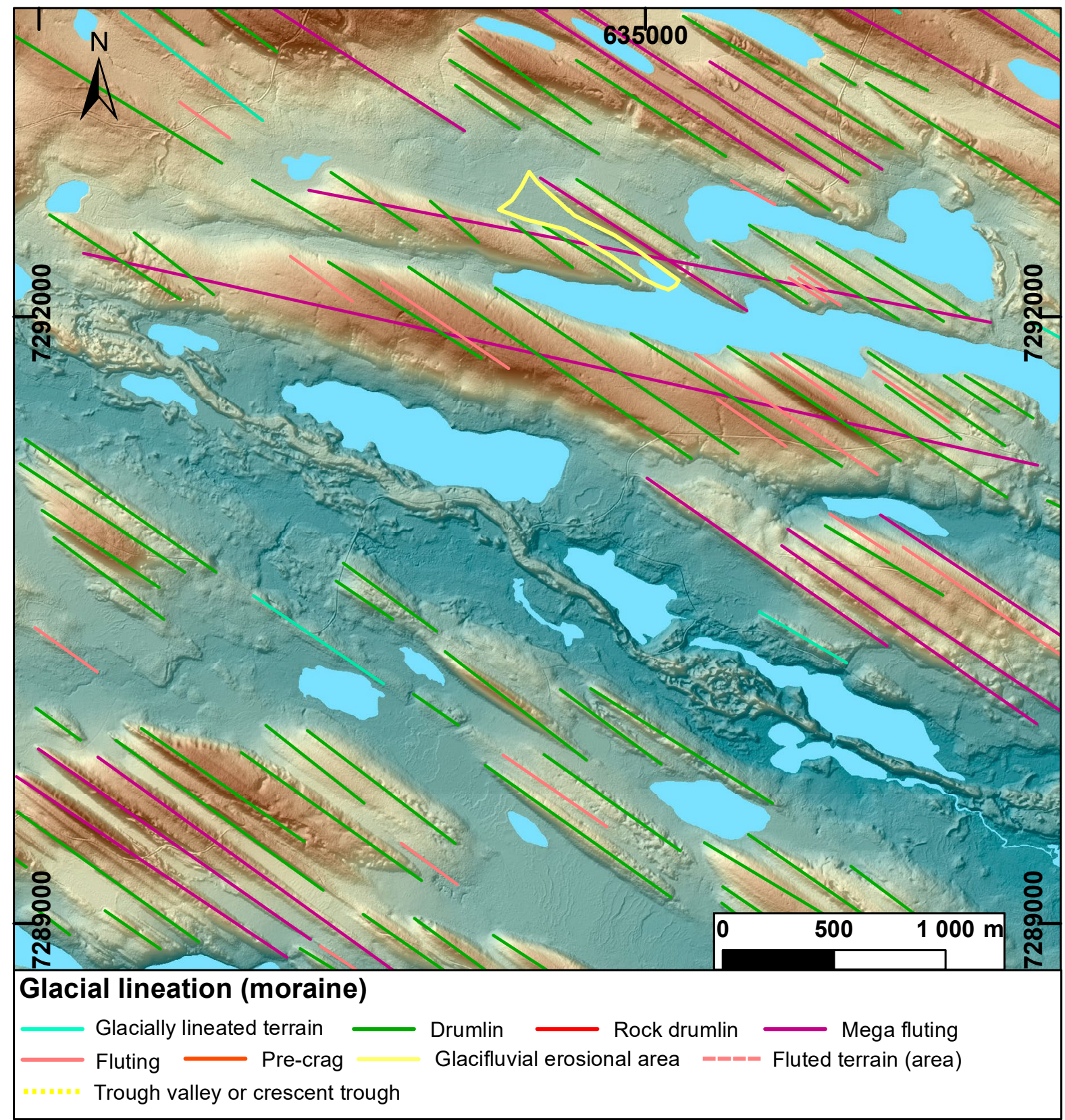

Figure 3. Drumlins, flutings and megascale glacial lineations (MSGLs) from different ice flow phases in the southeastern part of the Kuusamo Ice Lobe (KIL), close to the Russian border. Large and long, west-east oriented MSGLs represent the older Tuoppajärvi ice flow phase and younger lineations, mostly drumlins and flutings, represent the overlapping drumlin field of the later Kuusamo ice flow phase. Drumlins and flutings are typically very narrow and long in this part of KIL, indicating a fast-streaming glacier during deglaciation. A well-formed, sharp-edged esker formation crosses the centre of the map. Map produced by J. Räisänen. Coordinate system: EUREF-FIN. 
west-northwest to east-southeast orientated and usually long and wide features represent an older flow stage described by Aario and Forsström (1979) as the Tuoppajärvi ice flow phase. Single features are also found south of the main influence area of KIL. Uppermost morphologies mainly comprise northwest-southeast orientated drumlins and flutings, which represent the latest KIL flow direction during the latest deglaciation. In addition, there are valleys or topographic depression areas with the same direction between the lineation features fields or partly inside them. A typical feature is that the valleys seem to have some kind of systematic pattern with about $10-15 \mathrm{~km}$ intervals parallel to the ice flow direction (Fig. 1). These valleys are currently evident as narrow lakes or mire areas in the topography (Fig. 2).

High land areas are typically smoothed on top and covered by tens of small flutings. This kind of topography is classified as fluted terrain in the GTK's Glacier Dynamic database (see Putkinen et al., 2017, in this volume) or as streamlined terrain (Möller \& Dowling, 2015). An example of fluted terrain that formed on the top and distal side of the rocky hill area is presented in Figure 4. In this case, the lineations are formed of very small flutings, but also longer megaflutings with length up to $4 \mathrm{~km}$. In the down-ice direction (i.e. towards the east), the fluted terrain transits into the field of drumlins and flutings. The terrain is surrounded by erosional valleys, which are probably indicative of meltwater activity during and after the formation of the streamlined features.

A significant feature class in the KIL area is crescentic troughs. They are crescentic proximal gouges that were formed in front of obstacles (i.e. proximal part), such as drumlins and bedrock hills, during active ice flow (cf. Aario, 1977). In the KIL area, there are tens of large-scale features but also smaller features related to single drumlin ridges, usually on higher elevation. A good example is presented in the centre of Figure 5, where there is a well-developed, water-filled crescentic trough surrounding the $1.5 \mathrm{~km}$ long drumlin. Formation of those features indicates strong subglacial erosion and ploughing activity when the ice had to skirt obstacles in the down-ice direction.

In Figure 5, it is also possible to see the transition of the smoothed surface of drumlin into drumlin with indented surface. There is occasionally a transition into unformed hummocky moraine morphology, e.g. in the northeastern part. The indented surface of lineation features can also be seen in Figure 6, where there are fragmentary megaflutings (length more than $2 \mathrm{~km}$ ) indicating the flow direction of the latest ice flow. Surface structures resemble transversal channels that cut the moraine ridges. In many places, the fragmented drumlins and megaflutings occur in close proximity to subglacial meltwater channels and it is very likely that the fragmentation is related to meltwater activity with crevasse formation in the ice at the glacier margin. A similar origin is the most probable for the dead ice hummocks, the occurrence of which is also related to the subglacial meltwater channel systems (i.e. glaciofluvial esker systems) common in topographic depressions. Moraine features with indented surfaces can be seen everywhere in the KIL area and they resemble residual drumlins described by Möller and Dowling (2015) in southern Sweden.

\subsection{Hummocky and ribbed moraines}

Hummocky moraine areas include variable morphological types not classified in detail in this phase. Ribbed moraine fields composed of transversal ridges (Sarala, 2006) are dominant in the western parts of KIL. In many areas, they show clear transitional series from transversal hummocky ridges to Rogen moraines and fluted or drumlinised formations. This is characteristic of e.g. the fields in the Kemijärvi region (Fig. 7), where ribbed moraines are common in lowland areas and transition into drumlins and particularly into flutings in higher areas. In several places, small flutings occurring on top of the ribbed moraine ridges are also clearly evident in the LiDAR data.

Towards the east, hummock topography is most common in valleys, comprising unorientated 


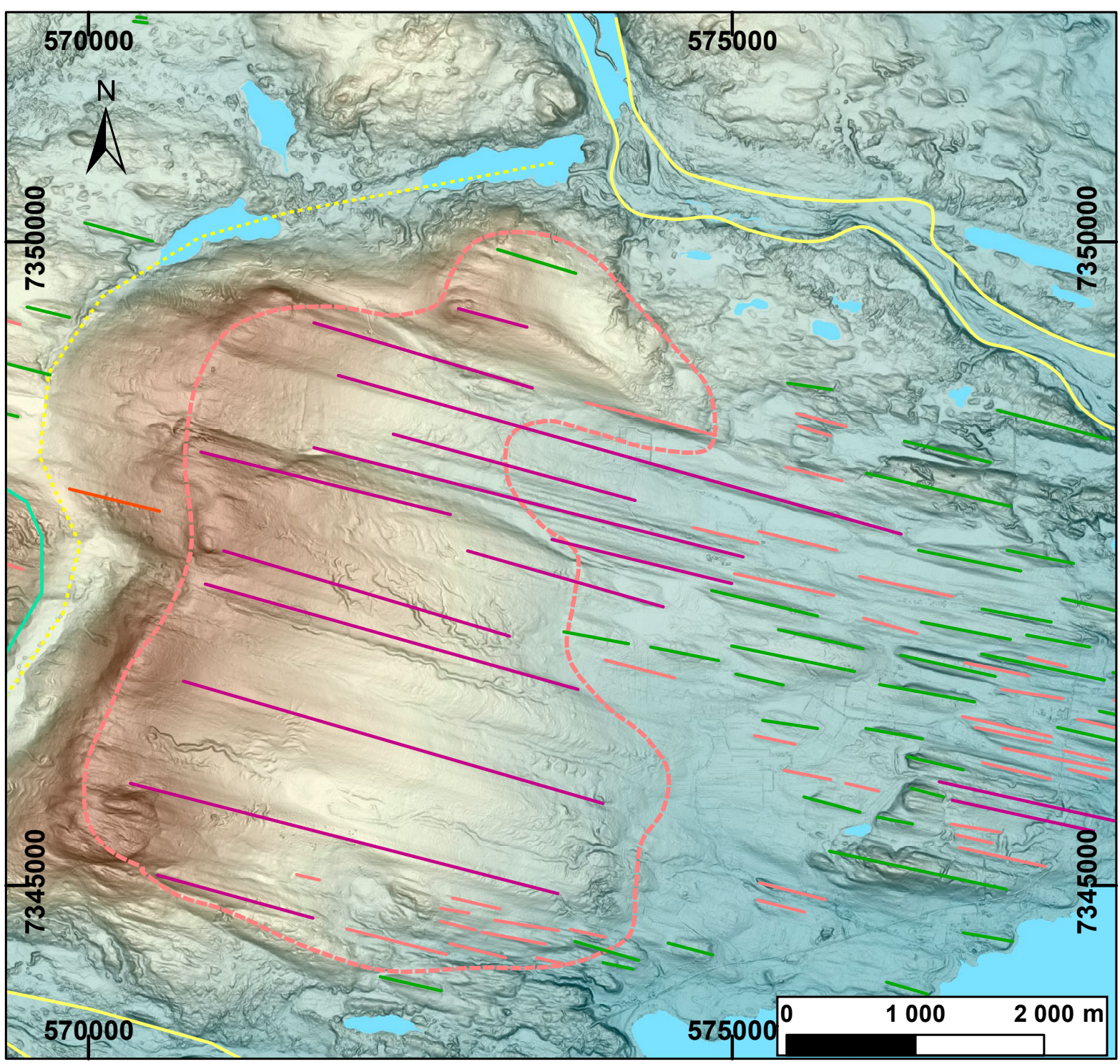

Figure 4. Example of fluted terrain on the distal side of the hill region in the centre of the study area, on the northwestern side of Lake Kitkajärvi. The terrain comprises up to $4 \mathrm{~km}$ long megaflutings representing the latest ice flow direction. In the down-ice direction, lineations transit to drumlins and flutings. An erosional valley and one pre-crag lineation can be seen on the proximal side of the hill. These kinds of fluted terrain are typical in the Kuusamo Ice Lobe (KIL) area, located at higher elevations. See the legend in Fig. 3. Map produced by J. Räisänen. Coordinate system: EUREF-FIN.

hummocky moraines or dead-ice moraines with kettle holes. These are closely related to meltwater systems with erosional channels and eskers. Only one larger, uniform hummocky moraine field exists in the eastern part, north of the Oulankajoki river valley.
End moraine ridges are rare in the KIL area. The main end moraine zone in KIL is located on the Russian side and only very small end moraine ridges are seen occasionally on the distal side of the large high land areas. Most of the minor end moraines occur in relation to flutings, indicating 


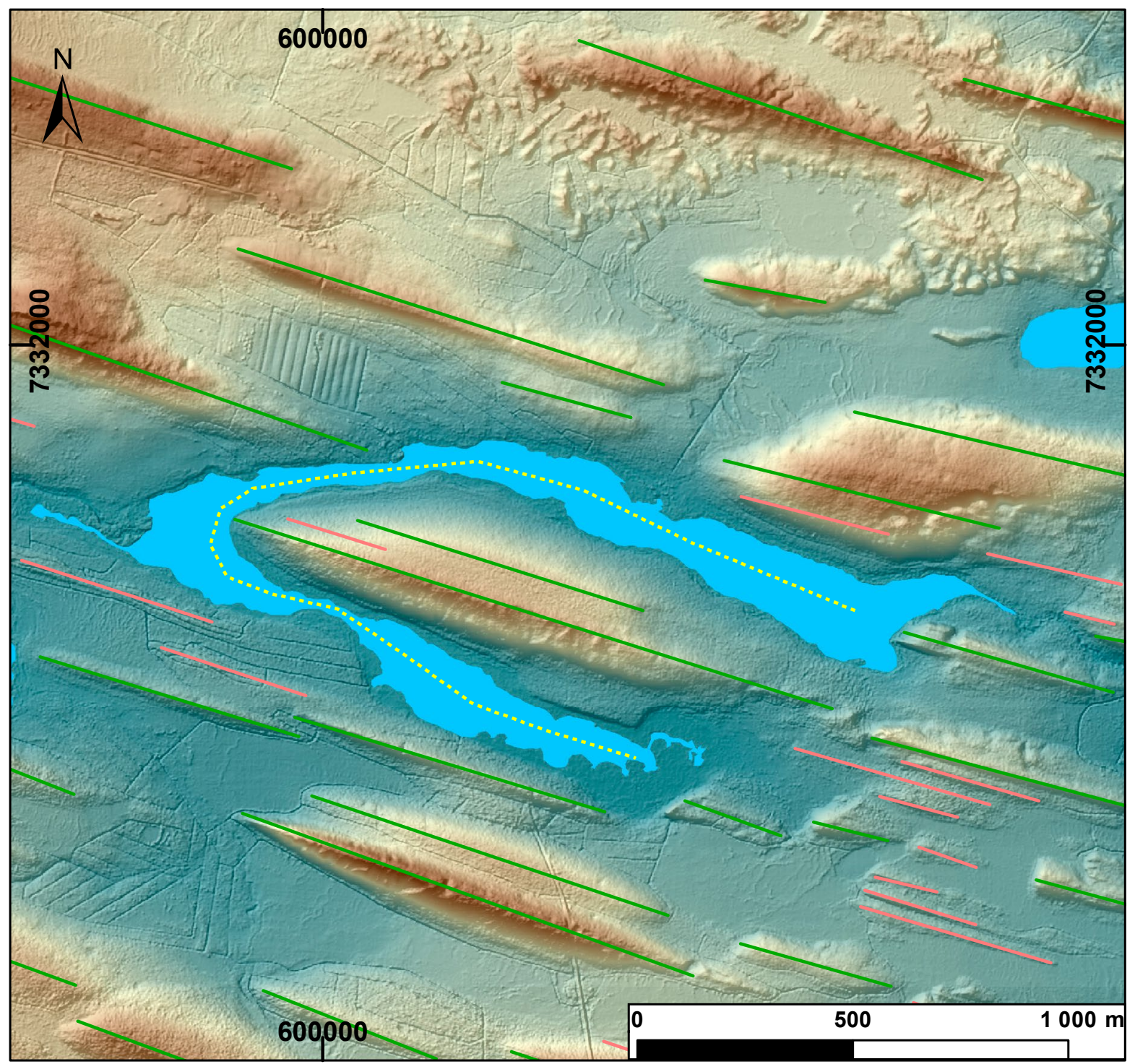

Figure 5. A well-formed crescentic trough on the proximal side of the $1.5 \mathrm{~km}$ long drumlin on the southern side of Ruka. The trough is evident as the water-filled erosional valley which continues on both sides of the drumlin. In the northern part of the map, the drumlins change from smooth-top ridges to indented-top forms. This indicates that the ice fractured and meltwater flowed under the ice to reshape and cut the drumlin and megascale glacial lineation (MSGL) topography. See the legend in Fig. 3. Map produced by J. Räisänen. Coordinate system: EUREF-FIN.

very late deposition at the margin of retreating but still moving ice. In the example in Figure 8, the end moraine ridges occur in the valley between the megaflutings or partly on top of them. End moraine ridges occur typically as a group with two to five ridges, which could lead to interpretation of these as DeGeer moraines. However, one typical feature of moraine ridges is that they occur in supra-aquatic positions, as seen in Figure 8. 


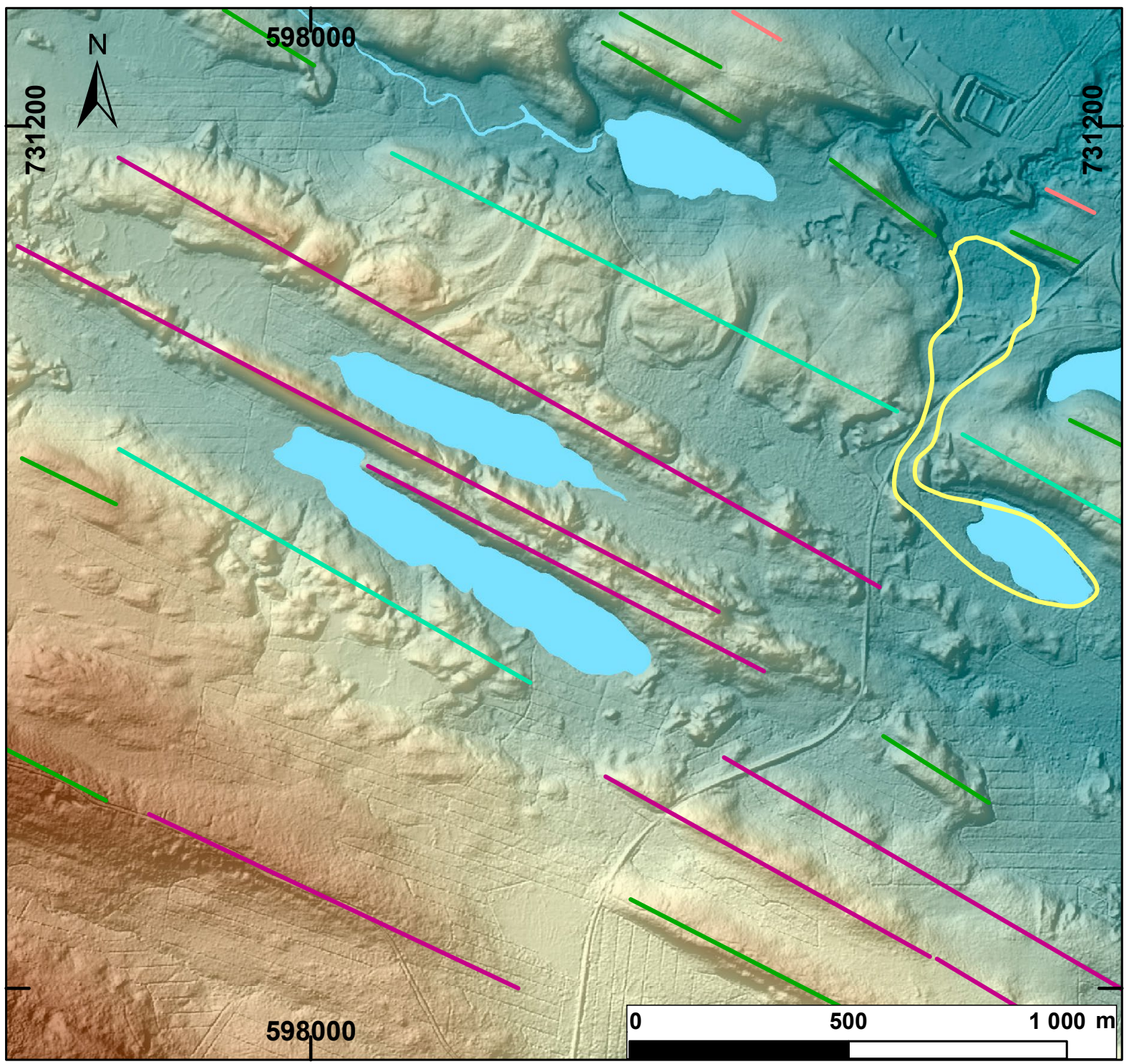

Figure 6. Megaflutings with channelised and hummocky surface, the formation of which is related to the last ice flow phase. However, in a later stage the glacier fractured and meltwater flowed under the ice, deforming and cutting the surface of lineations to form the indented surface. This type of morphology is typically found in the valleys in relation to meltwater channels. See the legend in Fig. 3. Map produced by J. Räisänen. Coordinate system: EUREF-FIN.

\subsection{Glaciofluvial and delta deposits}

Although the focus in this article is not on glaciofluvial formations, they are also easily identifiable based on the LiDAR data. Esker systems are easily mapped due to their narrow, sharp-edged shape and long, continuous patterns. Esker systems are often located in topographic depressions and weakness zones in the bedrock, which means that the directions of esker systems can differ from the direction of glacier flow. This is also the case in the KIL area. The most remarkable esker system cuts through the whole study area, from the Rovaniemi region to the Korouoma Gorge valley and from the 


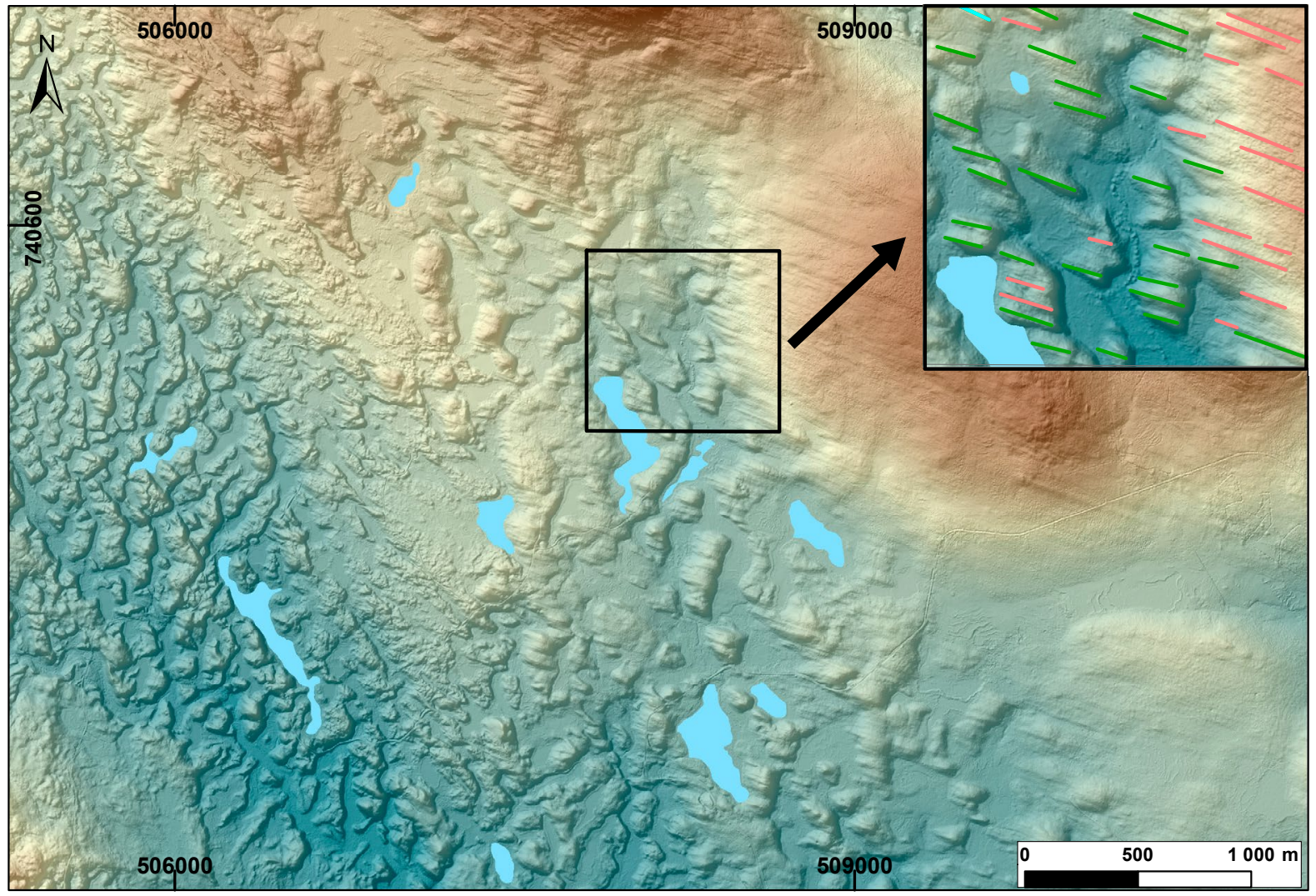

Figure 7. Transitional series of moraines from transversal hummocky ribbed moraines to Rogen moraines and finally to drumlinised and fluted terrain. The ice flow direction was from left to right. The area is located in the northwestern part of the study area and represents the core part of the Kuusamo Ice Lobe (KIL). The ribbed moraine formation is related to the cold-based/thawed-bed contact zone and the moving ice at a very late stage re-shaped the ridges, forming short lineations as tails or superimposed features. On higher elevation, ribbed moraines were eroded away and replaced with lineation terrain consisting of drumlins, flutings and pre-crags. See the legend in Fig. 3. Map produced by J. Räisänen. Coordinate system: EUREF-FIN.

Livojärvi and Kuusamo areas. In places, it forms a very wide esker network and there are sometimes even deltaic sediments in subglacial and/or supraaquatic conditions.

One deltaic deposition environment is presented in Figure 9. In this image, the core part of the esker crosses the southern part of the area, while the delta with several shoreline levels has developed into the northern side of the esker on the level of the ancient Kitka ice lake (highest shore line $252 \mathrm{~m}$ a.s.l.; Heikkinen \& Kurimo, 1977). Furthermore, there is another, slightly lower ice lake water level, of which shorelines can be seen in Figure 9. In the
LiDAR DEM, it is easy to see that the deltaic sand has been deposited over the drumlinised terrain. On the southern side of the delta in particular, sands and gravels cover older drumlins, which rise from the sand plateau like islands. On the northwest side of the delta, drumlins are very well-formed and easy to detect, although showing signs of disturbance caused by transversal meltwater channels.

In the KIL area, it is remarkable that meltwater channels are recognisable not only as eskers but also as strong erosional channels. These channels are cross-cutting lineations and have scoured reasonably deep channels parallel to the flutings and 


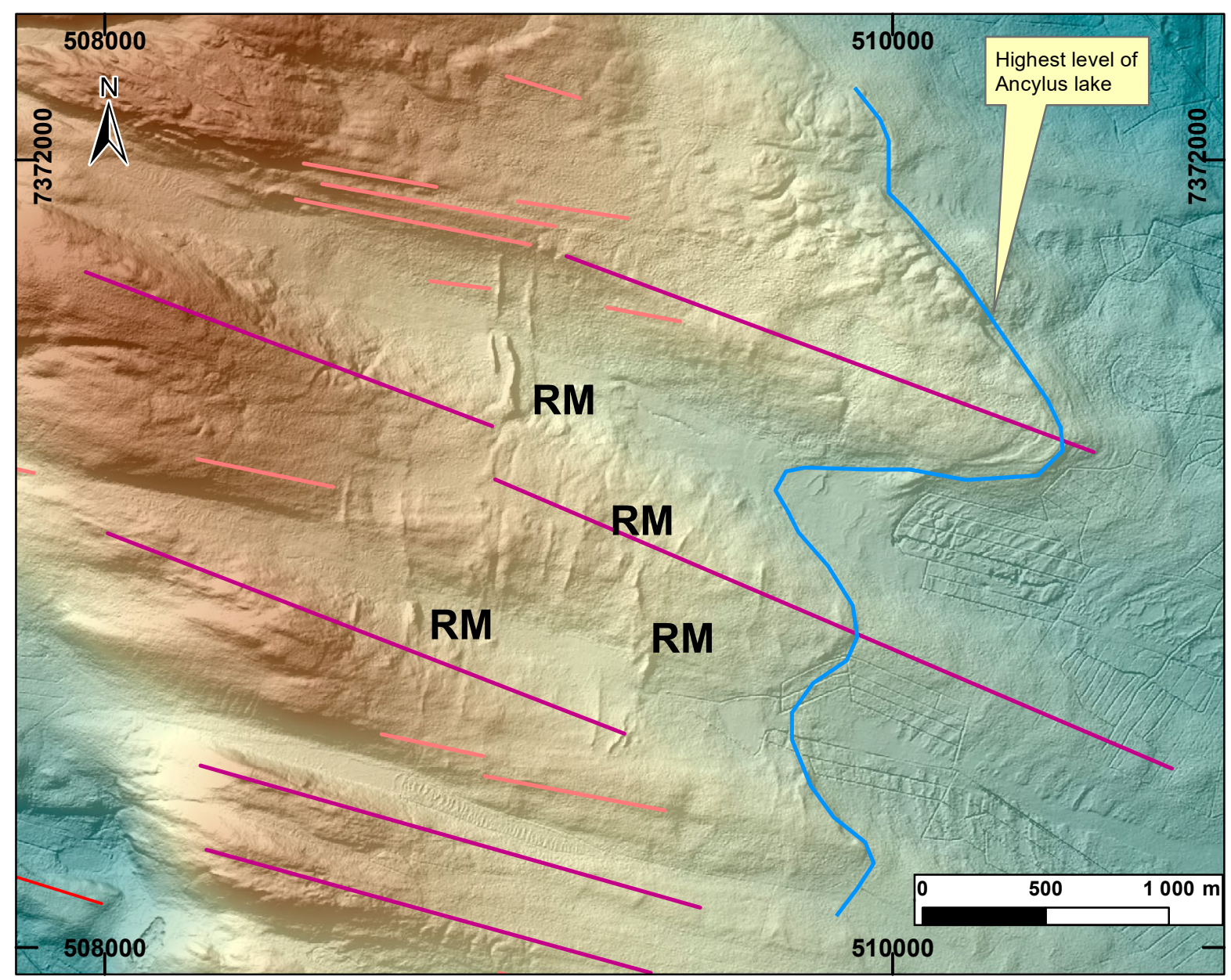

Figure 8. Small regression moraine ridges on top and between the megaflutings in the distal part of the higher elevation area in the western part of the Kuusamo Ice Lobe (KIL). The ridges resemble DeGeer moraines or minor end moraines, but in this case there are only five separate ridges without a wider continuum. The ridges are located above the highest shoreline of the lake Ancylus. See the legend in Fig. 3. Map produced by J. Räisänen. Coordinate system: EUREF-FIN.

drumlins or even through them. In the northern part of Figure 10, three drumlins can be seen in the present morphology. They might originally have been pre-crag forms on the proximal side of the eastern hills, but cut by the meltwater channels (marked as yellow line in Figure 10) in the later phase of deglaciation.

\section{Interpretation and discussion}

New glacial geomorphological mapping based on the LiDAR DEM data in the KIL area strengthened the earlier observation that two overlapping drumlin fields are present in the topography (cf. Aario \& Forsström, 1979). However, the new data also provide much more detail for glaciogenic feature observation than earlier aerial photos. Now it is possible to observe large areas covered by fluted surfaces, identify the broken surfaces of lineations 


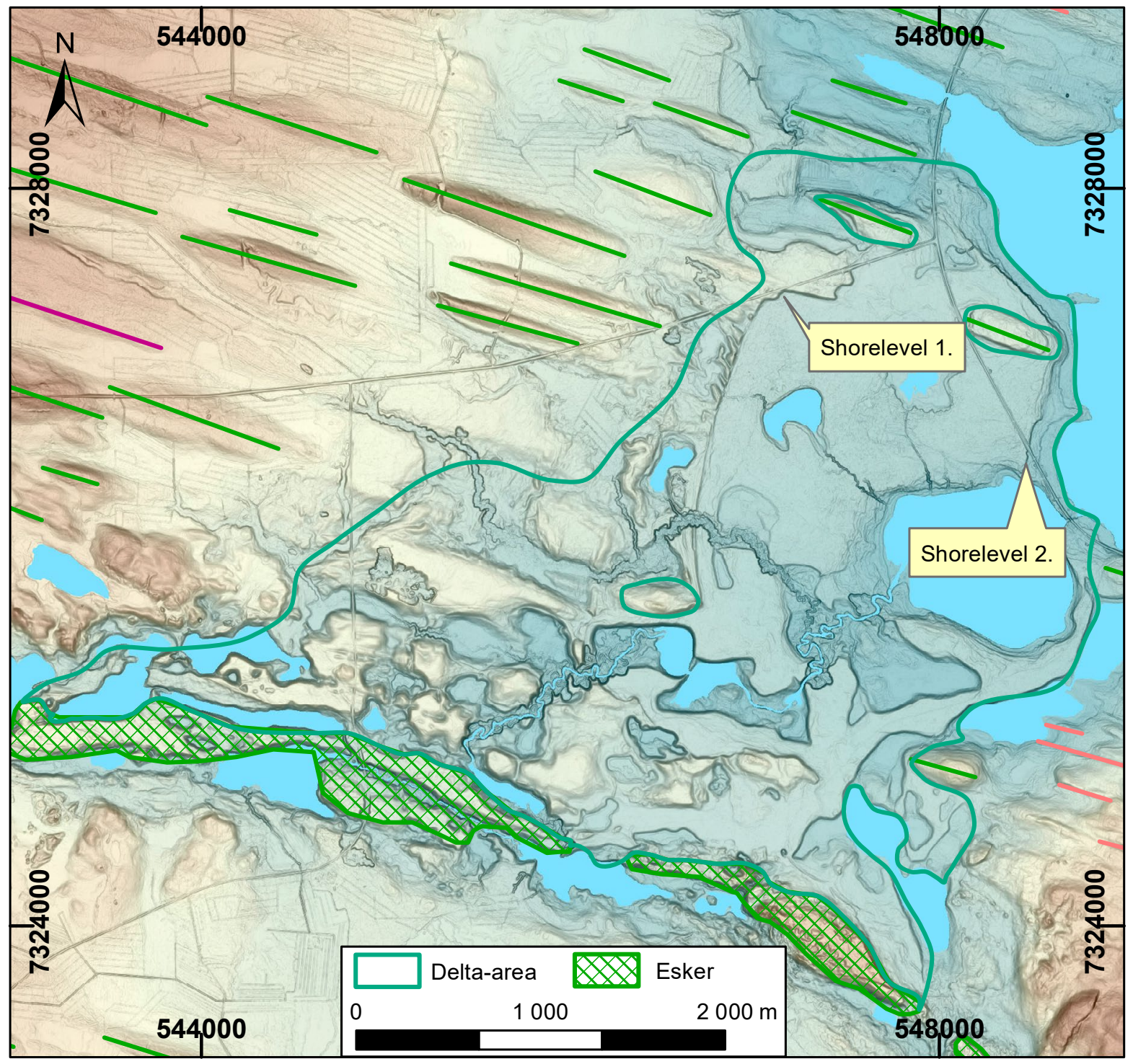

Figure 9. Deltaic deposit on the northern side of the esker system west of Lake Kitkajärvi. The delta material was deposited at the level of the ancient Kitkajärvi ice lake, the highest shoreline of which was at 252 m a.s.l. (Heikkinen \& Kurimo, 1977). A second, slightly lower shoreline level can also be seen on the delta surface. The delta is located in the drumlin area and the highest drumlin ridge tops can be seen emerging through the delta material. Outside the delta area, a well-formed drumlin field with some cutting meltwater channels continues on the northern and eastern sides. See the legend in Fig. 3. Map produced by J. Räisänen. Coordinate system: EUREF-FIN.

caused by cutting meltwater activity and discern even small end moraine ridges over the highest shorelines.

The dominant ice flow directions in the area have been from west to east, representing the older phase, and west-northwest to east-southeast, representing the younger flow phase of KIL. Of those, Aario \& Forsström (1979) named the first one the Tuoppajärvi phase and the second one the Kuusamo flow phase. However, in the LiDAR DEM data it was also possible to detect some older erosional and depositional marks under the 


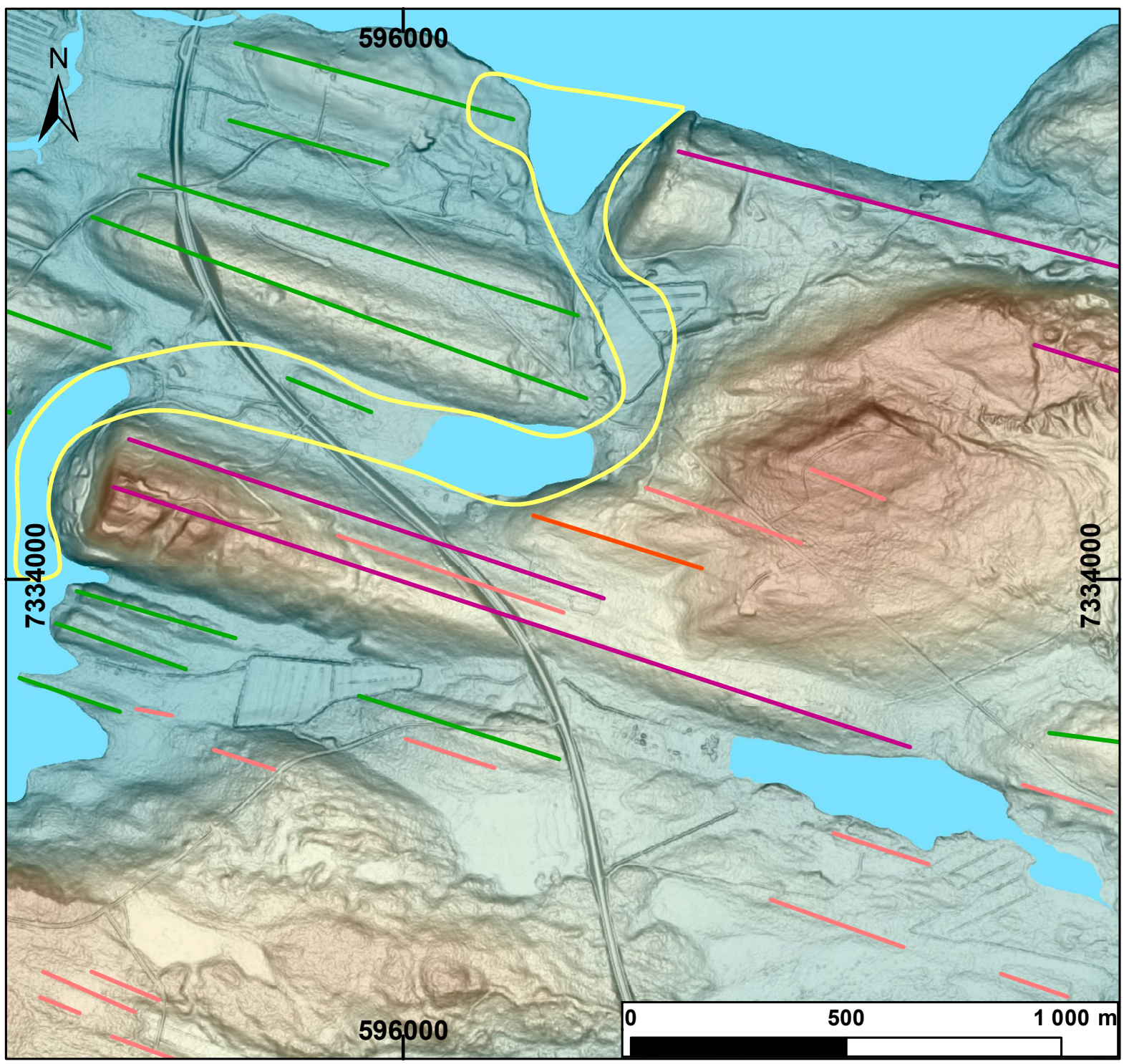

Figure 10. Different types of bedrock-dominated lineations near Ruka. In the middle of the map area is a $2 \mathrm{~km}$ long megafluting which was formed in the down-ice direction from the bedrock obstacle. This lineation type is also known as a crag and tail type formation. In the northern part of the map area, there are three drumlinoids that originated in pre-crag formations formed in the up-ice direction from the eastern bedrock hills. Later, the later meltwater erosional channel cut these from the bedrock connection. Pre-crag lineations are rare in the Kuusamo Ice Lobe (KIL) area. See the legend in Fig. 3. Map produced by J. Räisänen. Coordinate system: EUREF-FIN.

latest glaciogenic morphology (long, northwestsoutheast orientated lake valleys, megaflutings and glacially lineated terrains) indicating an earlier ice flow (Fig. 11). Sarala (2005a) reported lineations and erosional marks with the same orientation from the western KIL area and interpreted these as representing Middle Weichselian glaciation (MIS 4).

One aim with the new glaciogenic morphology identification and classification is re-interpretation of glacial dynamics and subglacial conditions 


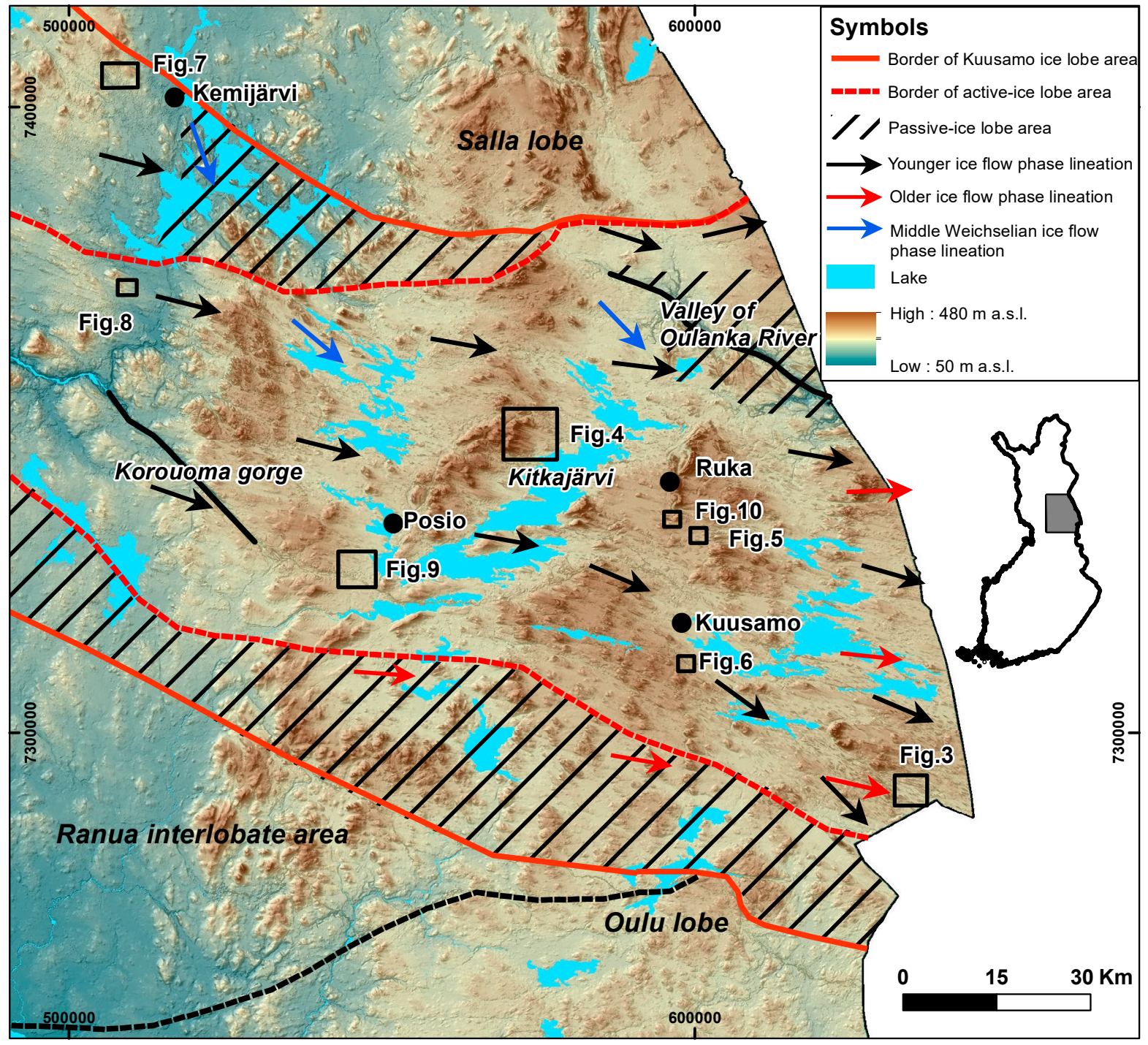

Figure 11. The generalised ice flow directions based on the mapped lineations and erosional features of different glacial phases in the eastern the Kuusamo Ice Lobe $(\mathrm{KIL})$ area, together with an interpretation of the ice lobe behaviour during the last deglaciation. Map produced by J. Räisänen. Coordinate system: EUREF-FIN.

during the last deglaciation. For this, the lineation framework in particular seems useful. For example, in the KIL area it can be seen that during the first phase of ice streaming, the lobe covered the whole area from the Oulu lobe in the south to the Salla lobe in the north and the margin reached to the Pääjärvi-Tuoppajärvi areas. This phase is evident as large west-east orientated megaflutings and drumlins throughout the whole KIL area. As the deglaciation continued and the glacier margin retreated towards Kuusamo, ice volume diminished in KIL and resulted in re-orientation of the ice lobe. Part of KIL remained fast flowing due to the continuum of snow accumulation in the core area, but at the same time glacier streams were more concentrated to narrow, surging type ice lobes. 
This phenomenon is very clearly evident in the KIL area, where the northern and southern parts of the larger KIL changed to passive lobe areas showing practically no indication of the latest westnorthwest to east-southeast orientated lineations (see Fig. 11).

Ribbed moraines are a large group of moraine ridges transverse to the ice flow direction. Morphology, inner and outer composition, lithology, fabric orientation and inner structures clearly reveal them to be subglacial depositional moraine formations with a close connection to cold/ thawed-bed glacial conditions (cf. Lundqvist, 1969, 1989; Aario, 1977; Aario \& Peuraniemi, 1992; Hättestrand, 1997; Kleman \& Hättestrand, 1999; Sarala et al., 1998; Sarala \& Rossi, 2000; Sarala, 2005b, 2006; Sarala \& Peuraniemi, 2007; Finlayson \& Bradwell, 2008; Trommelen et al., 2014; Möller \& Dowling, 2015). In KIL, the ribbed moraines change as the dominant morphology type in the core part of the ice lobe. This is the zone where the ribbed moraine formation happened in the subglacial conditions during the time-transgressive moving transition zone between cold-based and warm-based glacier (cf. Hättestrand, 1997; Kleman \& Hättestrand, 1999; Sarala, 2006). At the latest stages of retreat of the ice margin, short ice lobe activations and following movements caused reshaping of the ridges in several places. This resulted in the Rogen moraine-type morphology with drumlinised tails and fluted surface pointing in the down-ice direction. Furthermore, where glacier erosion during the later advance was strong, the ribbed moraine morphology was deformed or even replaced by drumlins and fluted surface. On higher elevation, fluted terrain and/or superimposed flutings over the drumlins were formed.

With the retreating ice margin, meltwater systems had to re-orientate. In the marginal parts of KIL (in the passive areas), esker systems followed the margins of large dead-ice blocks, forming interlobate complexes or contact esker systems between passive and active ice lobes. Meanwhile, the rapid melting of ice increased water inflow and led to the formation of a constant meltwater channel network (at $10-15 \mathrm{~km}$ intervals parallel to the ice flow direction; see Fig. 1). Following topographic depressions, the esker systems formed valleys. In these valleys, the dead-ice hummocky morphology and indented megaflutings or drumlins occur in close connection to meltwater systems. This indicates a strong influence of subglacial meltwater activity and ice fracturing during their formation. At the latest deglaciation phase, separate proglacial lake stages have left their mark on the topography as stratified deltaic deposits and the highest shorelines (see Fig. 9), and as burst-out meltwater channels such as the Korouoma Gorge valley (Fig. 2).

\section{Conclusions}

In this article, we describe new glaciomorphological mapping based on interpretation of LiDAR data and classification according to GTK's new Glacier Dynamic database. In the eastern part of the KIL area, strong streamlined lineation morphology and erosional features indicate that three different ice flow phases formed the modern surficial deposits. The remains of Middle Weichselian glaciation (northwest-southeast megalineations and erosional valleys) are seen only in places under the two overlapping drumlin fields of the Tuoppajärvi and Kuusamo ice flow phases during the Late Weichselian deglaciation. Together with the patterns of hummocky and ribbed moraine morphologies and glaciofluvial erosional and depositional systems, which are the lineations of different phases, it is possible to reconstruct ice lobe patterns in the separate phases and estimate the evolution and mass balance of KIL during the last deglaciation. Based on the existence of lineations and considering their types and orientations, it is possible to deduce a much larger and more homogeneous glacier stream during the Tuoppajärvi ice flow stage than the later Kuusamo ice flow stage, which was more concentrated, narrower and heterogeneous (of the lineation types), following a fan-type pattern. The fan-type pattern is also reflected in the meltwater channel systems, 
including both erosional and depositional features. Furthermore, on both margins (northern and southern), part of the ice masses formed stagnant areas. The length of the lineations also indicates both glacier flow velocity and transport distances, which in the case of MSGLs and drumlins are longer than in the fluted terrains. Ribbed-moraines in the western part, i.e. the core part of KIL, indicate very different depositional environment relating to strong quarrying and short transport distance under cold-based subglacial conditions, in the vicinity of the core area and late ice divide zone of SIS.

\section{References}

Aario, R., 1977. Associations of fluting, drumlins, hummocks and transverse ridges. Geojournal 1, 65-72. https://doi.org/10.1007/bf00195540

Aario, R., 1990. Morainic landforms in northern Finland. In: Aario, R. (ed.), Glacial heritage of Northern Finland; an excursion guide. Nordia tiedonantoja, Sarja A: 1, pp. 1327.

Aario, R. \& Forsström, L., 1979. Glacial stratigraphy of Koillismaa and North Kainuu, Finland. Fennia 157:2, $1-49$.

Aario, R. \& Peuraniemi, V., 1992. Glacial dispersal of till constituents in morainic landforms of different types. Geomorphology 6, 9-25. https://doi.org/10.1016/0169-555X(92)90044-O

Clark, C.D. \& Stokes, C.R., 2003. Palaeo-ice stream landsystem. In: Evans, D.J.A. (ed.), Glacial Landsystems. London, Arnold, pp. 204-227.

Finlayson, A.G. \& Bradwell, T., 2008. Morphological characteristics, formation and glaciological significance of Rogen moraine in northern Scotland. Geomorphology 101, 607-617. https://doi.org/10.1016/j.geomorph.2008.02.013

Hättestrand, C., 1997. Ribbed moraines in Sweden - distribution pattern and palaeoglaciological implications. Sedimentary Geology 111, 41-56. https://doi.org/10.1016/S0037-0738(97)00005-5

Heikkinen, O. \& Kurimo, H., 1977. The postglacial history of Kitkajärvi, North-eastern Finland, as indicated by trendsurface analysis and radiocarbon dating. Fennia 153 , $1-29$.

Johansson, P., 2005. Jääjärvet. In: Johansson, P. \& Kujansuu, R. (eds.), Pohjois-Suomen maaperä: maaperäkarttojen 1:400 000 selitys. Summary: Quaternary deposits of Northern Finland - explanation to the maps of Quaternary deposits 1:400 000. Geological Survey of Finland, Espoo, 127-148.

\section{Acknowledgements}

This article was produced as part of GTK's geomorphological mapping project focusing on glaciodynamics and new interpretation of ice lobe behaviour in Finland. The authors wish to thank the whole mapping crew of GTK and particularly thank Niko Putkinen, Jukka-Pekka Palmu, Peter Johansson, Satu Putkinen and Antti Ojala for discussion and helping during the mapping process. Many thanks also to Prof. Wojciech Wysota and Dr. Anna Hughes for their critical review and constructive comments.

Johansson, P. \& Kujansuu, R. (eds.), 2005a. Pohjois-Suomen maaperä: maaperäkarttojen 1:400 000 selitys. Summary: Quaternary deposits of Northern Finland - explanation to the maps of Quaternary deposits 1:400 000 . Geological Survey of Finland, Espoo, 236 p.

Johansson, P. \& Kujansuu, R., 2005b. Deglasiaatio. In: Johansson, P. \& Kujansuu, R. (eds.), Pohjois-Suomen maaperä: maaperäkarttojen 1:400 000 selitys. Summary: Quaternary deposits of Northern Finland - explanation to the maps of Quaternary deposits 1:400000. Geological Survey of Finland, Espoo, 149-156.

Kleman, J. \& Hättestrand, C., 1999. Frozen-bed Fennoscandinavian and Laurentide ice sheets during the Last Glacial Maximum. Nature 402, 63-66.

https://doi.org/10.1038/47005

Kleman, J., Hättestrand, C., Stroeven, A.P., Jansson, K.J., De Angelis, H. \& Borgström, I., 2006. Reconstruction of paleo-ice sheets-inversion of their glacial geomorphological record. In: Knight, P. (ed.), Glaciology and Earth's Changing Environment. Blackwell Publishing, pp. 192-198. https://doi.org/10.1002/9780470750636.ch38

Korsman, K. \& Koistinen, T., 1998. Suomen kallioperän pääpiirteet. In: Lehtinen, M., Nurmi, P. \& Rämö, T. (eds.), Suomen Kallioperä - 3000 vuosimiljoonaa. Suomen Geologinen Seura ry., pp. 93-103.

Kurimo, H., 1974. Virtaviivaiset muodot jään liikuntojen kuvastajina Posion-Kuusamon alueella. (Streamline features as indications of ice movements in the PosioKuusamo area, NE-Finland). Terra 86:2, 52-61.

Kurimo, H., 1982. Ice-lobe formation and function during the deglaciation in Finland and adjacent Soviet Karelia. Boreas 11, 59-78. https://doi.org/10.1111/j.1502-3885.1982.tb00522.x

Lundqvist, J., 1969. Problems of the so-called Rogen moraine. Swedish Geological Survey, 32 p. 
Lundqvist, J., 1989. Rogen (ribbed) moraine - identification and possible origin. Sedimentary Geology 62, 281-292. https://doi.org/10.1016/0037-0738(89)90119-X

Möller, P. \& Dowling, T.P.F., 2015. The importance of thermal boundary transitions on glacial geomorphology; mapping of ribbed/hummocky moraine and streamlined terrain from LiDAR, over Småland, South Sweden. GFF $137,1-32$. https://doi.org/10.1080/11035897.2015.1051736.

Ojala, A.E.K., Putkinen, N., Palmu, J.-P. \& Nenonen, K., 2015. Characterization of De Geer moraines in Finland based on LiDAR DEM mapping. GFF 137, 304-318. https://doi.org/10.1080/11035897.2015.1050449

Punkari, M., 1997. Subglacial processes of the Scandinavian Ice Sheet in Fennoscandia inferred from flow-parallel features and lithostratigraphy. Sedimentary Geology 111, 263-283. https://doi.org/10.1016/S0037-0738(97)00019-5

Putkinen, S., Putkinen, N., Sarala, P., Palmu, J.-P., Ojala, A. \& Ahtonen, N., 2016. Map database of superficial deposits and glaciodynamic features in Finland - methodology and classifications. In: Staboulis, S., Karvonen, T. \& Kujanpää, A. (eds.), Abstracts of the 32nd Nordic Geological Winter Meeting, 13th-15th January 2016, Helsinki, Finland. Bulletin of the Geological Society of Finland, Special Volume, pp. 310.

Putkinen, N., Eyles, N., Putkinen, S., Ojala, A.E.K., Palmu, J.-P., Sarala, P., Väänänen, T., Räisänen, J., Saarelainen, J., Ahtonen, N., Rönty, H., Kiiskinen, A., Rauhaniemi, T. \& Tervo, T. 2017. High-resolution LiDAR mapping of glacial landforms and ice streams in Finland. Bulletin of the Geological Society of Finland, this volume.

Räisänen, J., Johansson, P., Kejonen, A., Räsänen, J., Sarala, P., Valkama, J. \& Väisänen, U., 2012. Ruka - Oulanka: geological outdoor map, guidebook. Rovaniemi, Geological Survey of Finland, 51 p.

Sarala, P., 2005a. Weichselian stratigraphy, geomorphology and glacial dynamics in southern Finnish Lapland. Bulletin of the Geological Society of Finland 77:2, 71-104.

Sarala, P., 2005b. Till geochemistry in the ribbed moraine area of Peräpohjola, Finland. Applied Geochemistry 20, 1714-1736.

https://doi.org/10.1016/j.apgeochem.2005.04.018

Sarala, P., 2006. Ribbed moraine stratigraphy and formation in southern Finnish Lapland. Journal of Quaternary Science 21,387-398. https://doi.org/10.1002/jqs.995
Sarala, P. \& Peuraniemi V., 2007. Exploration using till geochemistry and heavy minerals in the ribbed moraine area of southern Finnish Lapland. Geochemistry: Exploration, Environment, Analysis 7, 195-205. https://doi.org/10.1144/1467-7873/07-126

Sarala, P., Peuraniemi, V. \& Aario, R., 1998. Glacial geology and till geochemistry in ore exploration studies in the Tervola area, southern Finnish Lapland. Bulletin of the Geological Society of Finland 70, 19-41.

Sarala, P., Räisänen, J., Johansson, P. \& Eskola, K.O., 2015. Aerial LiDAR analysis in geomorphological mapping and geochronological determination of surficial deposits in the Sodankylä region, northern Finland. GFF 137, 293 303. https://doi.org/10.1080/11035897.2015.1100213.

Sarala, P. \& Rossi, S., 2000. The application of till geochemistry in exploration in the Rogen moraine area at Petäjävaara, northern Finland. Journal of Geochemical Exploration 68, 87-104. https://doi.org/10.1016/S0375-6742(99)00060-6

Sarala, P. \& Rossi, S., 2006. Rovaniemen - Tervolan alueen glasiaalimorfologiset ja -stratigrafiset tutkimukset ja niiden soveltaminen geokemialliseen malminetsintään. Summary: Glacial geological and stratigraphical studies with applied geochemical exploration in the area of Rovaniemi and Tervola, southern Finnish Lapland. Geological Survey of Finland, Report of Investigations $161,115 \mathrm{p}$.

Silvennoinen, A., 1991. Geological map of Finland, explanations to the bedrock maps, map sheets $4524+$ 4542, Kuusamo and 4613, Rukatunturi. Geological Survey of Finland, Espoo, 62 p.

Smith, C.A. \& Peterson, G., 2014. Quaternary geomorphology of the Siljan area, central Sweden. Journal of Maps 10, 521-528. https://doi.org/10.1080/17445647.2014.890958

Sutinen, R., 1992. Glacial deposits, their electrical properties and surveying by image interpretation and ground penetrating radar. Geological Survey of Finland, Bulletin $359,123 \mathrm{p}$.

Trommelen, M.S., Ross, M. \& Ismail, A., 2014. Ribbed moraines in northern Manitoba, Canada: characteristics and preservation as part of a subglacial bed mosaic near the core regions of ice sheets. Quaternary Science Reviews $87,135-155$.

https://doi.org/10.1016/j.quascirev.2014.01.010 